\title{
Community, Confederation, and Corpus Christianum: Defining "Gemeinde" in Huldrych Zwingli's Thought, 1525-1531'
}

Kirk W. Goodlet, University of Waterloo

\begin{abstract}
This essay investigates Zwingli's lexicon relating to "Gemeinde" (community) in his writing and provides an in-depth look at how this concept shaped the Reformation in Zurich and the Swiss Confederation. Far from the reductive idea of community which was limited to one's confraternity, guild, or network of kinship, Zwingli's concept of community was inherently linked to the Confederation and the broader corpus christianum. Through baptism and the Lord's Supper, all those Swiss living in accordance with Scripture became members of a larger transcendental Swiss community. The Reformation of the Confederation, for Zwingli, became a precondition for remaining God's elect.
\end{abstract}

\section{Introduction}

"Beware, Schwyz, of foreign lords; they would bring you dishonor." 2

With these words, the Protestant reformer of Zurich, Huldrych Zwingli (1484-1531), concluded his Divine Exhortation to the Confederates of Schwytz (1522). In his treatise, Zwingli enumerated five reasons why Schwyz, one of the founding members of the Old Confederacy in 1291, which also included the so-called original cantons (Urkantone) of Uri and Unterwalden, should avoid sending Swiss men as mercenaries to fight alongside Italian or French armies. ${ }^{3}$ The bellicose reputation the Swiss acquired during the Middle Ages led some cantons to sign agreements with French and Italian nobles interested in hiring

\footnotetext{
${ }^{1}$ I would like to thank the two anonymous reviewers at Past Imperfect, as well as Randolph Head at the University of California-Riverside who read over multiple drafts of the paper and whose perceptive comments were indispensable to this essay.

2 "Hůt dich, Schwytz, vor frömbden heren; Sy brächtend dich zů uneeren"CRR (Center for Reformation Research, St. Louis, MO) 1011/1-2565; Cf. Z (Huldreich Zwinglis Sämtliche Werke, Corpus Reformatorum), I, 188.

${ }^{3}$ For an excellent background on the development of the Swiss Confederation from the thirteenth century onwards, see Guy P. Marchal, Ulrich Im Hof, et al. Geschichte der Schweiz- und der Schweizer I. Band (A History of Switzerland and the Swiss) (Basel: Helbing \& Lichtenhahn Verlag AG, 1982), 124-141; Guy P. Marchal, Schweizer Gebrauchgeschichte: Geschichtsbilder, Mythenbildung und Nationale Identität (The Swiss Use of History: History, Myth, and National Identity) (Basel: Schwabe Verlag, 2006), 60-76.
} 
them as mercenaries, and eventually Swiss mercenaries were controlled like other export commodities. ${ }^{4}$ Zwingli condemned the actions of foreign lords and their wars that tainted justice and the law. ${ }^{5}$ Following their return from such wars, Swiss men brought with them perverted morals like drinking, pompous clothing, and profanity. Pensions and gifts from foreign lords also provoked jealousy among the Swiss people and encouraged the wrath of God. All of these threats, Zwingli warned, would lead to the destruction of the Confederation. ${ }^{6}$ In many ways, this treatise captures aptly Zwingli's ideas regarding the Confederation and its importance for mutual protection against what he considered foreign forces, those spiritual and temporal threats from outside the Swiss lands. For Zwingli, the preservation of the Confederation required its members to cease relations with non-Swiss powers. As his Divine Exhortation makes clear, he wrote about this with a sense of urgency. What reasons lay behind his exigent admonition and why was Zwingli so concerned with Schwyz's involvement in the mercenary trade? On its surface, this treatise shows us how ardently Zwingli opposed the mercenary system and its effects on Swiss lands. Yet, on another level, it is also very instructive in helping us understand what the Confederation meant to Zwingli during his lifetime.

Zwingli believed that the salvation of the Confederation depended on spreading the Gospel, and this meant that, during the Reformation, he saw not only Zurich but the entire Confederation as vital to the success of his socio-religious programme. Throughout the 1520s, Zwingli wrote a number of treatises that addressed the Confederation and its importance in the Reformation cause, imbuing a sense of holiness in the Swiss. ${ }^{7}$ He believed that the Confederation consisted of a broader

\footnotetext{
${ }^{4}$ John McCormack, One Million Mercenaries: Swiss Soldiers in the Armies of the World (London: Leo Cooper, 1993).

${ }^{5}$ By "foreign" I mean nobles and kings living outside the Confederation and affiliated states. This concept of foreignness was fairly popular among Swiss humanists during the sixteenth century.

${ }^{6} \mathrm{Z}$ I, 188. Zwingli also wrote that his admonition for Schwyzers was made "from the fear of God and the love of the honoured Confederation."

${ }^{7}$ CRR, 1051/1-2659 "Ein freundlich Bitt und Ermahnung etlicher Priester der Aidgenossschaft, daß man das heilig Evangelium predigen nicht abschlage" (1522); CRR 1484/1-3892 "Ein freundliche Geschrift an gemein Aidgenossen der XII Orten und Zugewanten" (1526); CRR 995/1-2525 "Ein trüw und ernstlich Vermahnung an die frommen Aidgenossen, daß die sich nach ihrer Vordren Brauch und Gestalt leiten".
} 
community (Gemeinde) to which all Christians belonged, and that community and Confederation were inextricably linked, a concept that developed out of his theological and socio-political understanding of the world in which he lived. ${ }^{8}$

Many historians use the word Gemeinde to explain social, economic, political, and familial relationships in medieval and early modern Germany and Switzerland, and some may use it without evaluating what it meant to sixteenth-century Europeans. ${ }^{9}$ This paper examines Zwingli's lexicon relating to Gemeinde and provides an indepth look at how his idea of community shaped the Reformation in Zurich and parts of the Confederation. It specifically focuses on the rhetorical and idealistic lexicon of community advanced by Zwingli and his followers. And while his ideal concept of community influenced community definition in practice to some extent, we are chiefly concerned with his language relating to community. Far from the reductive idea of community which was limited to one's confraternity, guild, or network of kinship, Zwingli's concept of community was inherently linked to the Confederation and the broader corpus christianum. $^{10}$ For Zwingli, community transcended town borders: through baptism and the Lord's Supper, all those Swiss living in accordance with Scripture became members of a larger transcendental Christian community. For that reason, Zwingli believed he and other

\footnotetext{
${ }^{8}$ There is something to be said about the connection between the origins of the Confederation, or in Swiss German Eydgenossenschaft (literally cooperative oath), and Zwingli's perception of the Eucharist and Baptism as symbols or oaths to enter and pledge allegiance to a community. His understanding of the sacraments was considerably influenced by his politics and the development of his patria. See my discussion on the sacraments and Zwingli's use of Gemeinde below.

${ }^{9}$ See Bob Scribner's assessment of the term in "Communities and the Nature of Power" in Germany: A New Social and Economic History, 1450-1630, vol. I, edited by Bob Scribner (New York: St. Martin's Press, 1996), 291-325; Tom Scott and Bob Scribner, "Urban Networks: The German Town: definition, size, and economic structure," in Germany: A New Social History, 113-143; Jason P. Coy, Strangers and Misfits: Banishment, Social Control, and Authority in Early Modern Germany (Leiden: Brill, 2008); Lee Palmer Wandel, Always Among Us: Images of the Poor in Zwingli's Zurich (Cambridge: Cambridge University Press, 1990); Judith Pollmann, "Catholics and Community in the Revolt of the Netherlands," in Living with Religious Diversity in Early-Modern Europe edited by C. Scott Dixon and Mark Greengrass (Burlington, VT: Ashgate, 2009), 183-202.

${ }^{10}$ Michael Mitterauer and Reinhard Seider, The European Family: Patriarchy and Partnership from the Middle Ages to the Present Trans. By Karla Oosterveen and Manfred Horzinger. (Oxford: Basil Blackwell, 1982), 7ff; James M. Stayer, Anabaptists and the Sword (Lawrence, KS: Coronado Press, 1972), 50.
} 
reformers, like Oecolampadius and Berchthold Haller, needed to spread the Reformation to other territories in the Confederation. For the same reason, he also believed that true Christians, those who adhered to reformed sacraments, needed to eradicate all temporal and spiritual threats within the Confederation. This, for Zwingli, prevented groups like the Anabaptists from impeding the community's regeneration and preparation for the imminent Last Days. ${ }^{11}$

\section{Concepts of Gemeinde and its Uses in Reformation History}

Although many scholars criticize Ferdinand Tönnies' differentiation between the pre-modern Gemeinschaft (community) based on personal and localized relationships, and the modern Gesellschaft (society) based on largely impersonal and defined by institution-based interactions, others tacitly or partially accept his model by emphasizing the locality of pre-modern definitions of community. ${ }^{12}$ In other words, and as this section illustrates, the idea that community in early modern Europe implied something local or based on personal relationships remains fairly popular among some historians. Other historians, however, have criticized Tönnies' model explicitly. ${ }^{13}$ Examination of Zwingli's lexicon reveals that Tönnies' supposition is inadequate to deal with Zwingli's more inclusive concept of community, which he saw as a universal body of Christians. The studies discussed below examine the construction of actual communities, rather than rhetorical or magisterial uses of community advanced by ecclesiastical and political figures. It is less popular to focus on rhetorical uses of community put forth by sixteenth-century theologians and reformers, and the paucity of literature surrounding Zwingli's ideas regarding community substantiates this

\footnotetext{
${ }^{11}$ For more on apocalyptic thought in early sixteenth-century Zurich, see Irena Backus, Reformation Readings of the Apocolypse: Geneva, Zurich, and Wittenberg (Oxford: Oxford University Press, 2000), 87-112.

${ }^{12}$ Ferdinand Tönnies, Gemeinschaft und Gesellschaft (Community and Society) (Darmstadt: Wissenschaftliche Buchgesellschaft, 1887/1963).

${ }^{13}$ Katherine Lynch, Individuals, Families, and Communities in Europe, 1200-1800, (Cambridge: Cambridge University Press, 2003), 14.
} 
claim. ${ }^{14}$ Nevertheless, Zwingli envisaged a community in which all confederates adopted the Reformation and pledged allegiance through baptism and the Lord's Supper, and he saw this as a realistic possibility throughout his life despite the political and religious opposition within the Confederation. His ideal concept of community and the language he used to describe it, therefore, remains an important part of the Reformation for historians to study if they seek to understand what community meant to a religious figure that undoubtedly shaped the course of ecclesio-political change in Zurich and beyond. Indeed, Calvinism, which later became incredibly influential in Europe and elsewhere, owes much more to Zwinglianism than historians have recognized. This essay contributes to the growing body of literature that defines community in early modern Europe, but it posits that Zwingli's concept of community transcended local borders to include the Swiss Confederation and all Christians residing therein, forming a corpus christianum. ${ }^{15}$

This study builds on a growing body of literature interested in defining what community membership meant to early modern Europeans. ${ }^{16}$ Scholars like Peter Blickle, Robert Scribner, and Joel Harrington have contributed significantly to current ideas about community in early modern Europe, and they have addressed how religious, social, and economic factors determined official and popular

\footnotetext{
${ }^{14}$ See for instance, Benedict Anderson's Imagined Communities: Revised Edition (Verso: London, 2006) and The Reformation in National Context edited by Robert Scribner, Roy Porter, and Mikulas Teich (Cambridge: Cambridge University Press, 1994); Brigitte Brockelmann, "Das Corpus Christianum bei Zwingli" (The Corpus Christianum of Zwingli) in Breslauer historische Forschungen 5 (Breslau: Prietbatschs Buchhandlung, 1938); Lee Palmer Wandel, "Brothers and Neighbors: The Language of Community in Zwingli's Preaching," in Zwingliana 17/1 (1988), 361-374.

${ }^{15}$ Otto von Gierke's Das deutsche Genossenschaftsrecht I-IV (German Cooperative Law I-IV) (Berlin, 1868).

${ }^{16}$ For instance Susan C. Karant-Nunn, Zwickau in Transition 1500-1547 (Columbus, OH: Ohio State University Press, 1987); Lyndal Roper, The Holy Household: Women and Morals in Reformation Augsburg (Oxford: Oxford University Press, 1989); Philip T. Hoffman, Church and Community in the Diocese of Lyon, 1500-1789 (New Haven: Yale University Press, 1984); Norbert Schindler, Rebellion, Community and Custom in Early Modern Germany trans. Pamela E. Selwyn (Cambridge: Cambridge University Press, 2002); Charles H. Parker and Jerry H. Bentley, Between the Middle Ages and Modernity: Individual and Community in the Early Modern World (Lanham, MD: Rowman \& Littlefield, 2007); Coy, Strangers and Misfits: Banishment, Social Control, and Authority in Early Modern Germany (Leiden: Brill, 2008); Joel F. Harrington, The Unwanted Child: The Fate of Foundlings, Orphans, and Juvenile Criminals in Early Modern Germany (Chicago: Chicago University Press, 2009).
} 
definitions of community. ${ }^{17}$ For the most part, these scholars focus on definitions of community in towns. Peter Blickle, much of whose work focuses on the rural Reformation and brings some balance to the discussion, argues that the "common man" significantly influenced the structure of authority in the early decades of the Reformation. He points out that because reformed theology was mediated through the medieval institution of the commune, or shared common lands, "Communal Reformation" is a much better term for the early Reformation than urban or magisterial. ${ }^{18}$ Blickle's work and his shift away from urban settings provide historians with a balanced and a nuanced look at community membership and its definition in the rural regions of sixteenth-century Germany and Switzerland. ${ }^{19}$

Other historians, like Robert Scribner, have paid close attention to the complexity of early modern definitions of community. His work on communities in early modern Germany shows that concepts of community were closely related to power, regardless of urban or rural vocation. Scribner demonstrates that both rural and urban populations defined their communities simultaneously, though urban constructions differed greatly as a result of rising guilds and the decline of feudal lordship in the eleventh and twelfth centuries. During the twelfth century, Scribner argues, more intense agricultural cultivation led to the creation of "nuclear," or centralized, villages that followed a threefold crop rotation. This agricultural system forced farmers to draw up sets of rules relating to harvests and for centuries this helped define community membership in parts of the German lands. ${ }^{20}$ Here, too, community

${ }^{17}$ For instance, Robert M. Kingdon, "The Control of Morals in Calvin's Geneva," in The Social History of the Reformation translated by Lawrence P. Buck and Jonathan W. Zophy (Columbus: Ohio University Press, 1972); Katherine A. Lynch, Individuals, Families, and Communities in Europe, 1200-1800 (Cambridge: Cambridge University Press, 2003).

${ }^{18}$ Peter Blickle, Revolution of 1525, translated by T. A. Brady Jr. and H.C.E. Midelfort (Baltimore, ML: John Hopkins University Press, 1981); Blickle, From the Communal Reformation to the Reformation of the Common Man translated by Beat Kümin (Leiden: Brill, 1998).

${ }^{19}$ André Holenstein, "Reformation und Konfessionalisierung in der Geschichtsforschung der Deutschschweiz," (The Reformation and Confessionalization in Historical Research on German-Switzerland) in Archiv für Reformationsgeschichte 100 (2009), 65-85

${ }^{20}$ Scribner, "Communities and the Nature of Power" in Germany: A New Social and Economic History, 1450-1630, vol. I, edited by Bob Scribner (New York: St. Martin's Press, 1996), 299; Blickle, Deutsche Untertanen: Ein Widerspruch (German Subjects: A Contradiction) (München: Beck, 1981). 
definition is understood as something local and highly dependent on social status or vocation.

In a similar way, Joel Harrington has shown that child circulation in early modern Germany influenced community definition. He investigates the ways in which policies governing child circulation and unwanted children in Nuremberg defined community dynamics and how city regulations were not always applied uniformly. The Nuremberg regulations stipulated that any abandoned child from outside the city should be left outside the city walls, a regulation that sought to reinforce community membership by denying certain rights to outsiders. However, Harrington uncovers a considerable number of cases where the Findel, or town orphanage, dealt with children from outside the city in the same way it dealt with children from Nuremberg. He concludes that an examination of child circulation in early modern Nuremberg illustrates that urban communities were sometimes "much more flexible and porous than posited by 'essentialist and mystical' concepts of Gemeinschaft."21 Albert Häuser similarly recognizes the flexibility by which communities were defined in fifteenth and sixteenth century Switzerland. He argues, following the work of Otto Brunner that in some cases community membership was defined by cohabitation, which may have included apprentices, domestic workers, and extended family. ${ }^{22}$ Community, neighbourhood, brotherhood and guild, Häuser points out, represent the different ways in which community membership was determined in late medieval and early modern Switzerland. ${ }^{23}$

Recent research into early modern German banishment practices reinforces similar conclusions made by Harrington and Häuser, which

${ }^{21}$ Joel F. Harrington, "Child Circulation within the Early Modern Urban Community: Rejection and Support of Unwanted Children in Nuremberg," in Defining Community in Early Modern Europe edited by Michael J. Halvorson and Karen E. Spierling (Aldershot, UK: Ashgate, 2008), 119; Harrington, The Unwanted Child, Introduction.

${ }^{22}$ Albert Häuser, Was für ein Leben:Schweizer Alltag vom 15. Bis 18. Jahrhundert (What a Life: Everyday Life in Switzerland from the $15^{\text {th }}$ to $18^{\text {th }}$ Century) (Zürich: Verlag Neue Zürcher Zeitung, 1987), 211-220; Otto Brunner in Land und Herrschaft: Grundfragen der territorialen Verfassungsgeschichte Südostdeutschlands im Mittelalter (Wien:Veröffentlichungen des Instituts für Geschichtsforschung und Archivwissenschaft, 1939). Brunner's work was translated into English as Land and Lordship: Structures of Governance in Medieval Austria, trans. Howard Kaminsky and James Van Horn Melton (Philadelphia: University of Pennsylvania Press, 1992).

${ }^{23}$ Häuser, Was für ein Leben: Schweizer Alltag vom 15. Bis 18. Jahrhundert, 211-220. 
suggests that punishments of exile and purgation helped define community by eradicating threats to local social order. ${ }^{24}$ In all three studies, community definition is measured in terms of physical and local interaction whether by the inclusion in or exclusion from particular social relationships, ties, or networks.

In his work on sixteenth-century Zurich, Robert Walton examines the relationship between the clergy and magistrates that grew out of Zwingli's reformation program in Zurich. Walton notes that his work rests upon the assumption that men thought of society as a single Christian body, a corpus christianum, whose government and purpose had been ordained by God. ${ }^{25}$ While he convincingly points out that "Zwingli believed in a Christian society ruled by two God-ordained officers, the magistrate and the pastor," Walton also implies that Zwingli emphasized the exclusivity of Zurich's Christian society. ${ }^{26}$ As this study will show, however, Walton's connection between Zwingli's teaching and his desire to form a corpus christianum limited to Zurich inadequately accounts for his ambition to spread the Gospel throughout the entire Confederation and establish a universal Swiss church. This paper goes one step further and proposes that Zwingli aimed to connect the Confederation through evangelical teaching and he intimately associated the salvation of the Confederation and community.

Before turning to Zwingli's concept of community, some of the terms historians use to define community in early modern Germany and Switzerland require assessment. There is a long historiographical tradition in both English and German-language literature to explain premodern relationships by focusing on the most basic and fundamental forms of social organization. The studies mentioned above highlight the multivalent nature of early modern communities and how they were constructed, and that community membership varied according to the complexion of contemporary economic, social, familial, or religious forces. There often existed conflicting and competing concepts of

\footnotetext{
${ }^{24}$ Coy, Strangers and Misfits: Banishment, Social Control, and Authority in Early Modern Germany (Leiden: Brill, 2008)

${ }^{25}$ Robert C. Walton, Zwingli's Theocracy (Toronto: University of Toronto Press, 1967), Introduction.

${ }^{26}$ Walton, Zwinglis Theocracy, $\mathrm{x}$.
} 
community depending on the interaction of these forces, and the construction of communities was neither static nor as concrete as magisterial conceptions portrayed. Historians use the terms Gemeinde and Gemeinschaft most frequently, but other terms can be used like Genossenschaft (corporate or collective association) or Allmende (referring to common lands) to describe the development of community. Translating Gemeinde as "community" or "commune" does not sufficiently denote its range of meanings and conceptions in the German language. It could refer to the common land held by a community, to a territorially limited set of social affiliations, or to the "commons" in the sense of the people. ${ }^{27}$ In his study, Scribner has noted that the complexity of meaning arises when authorities in the late Middle Ages and early modern period began to use the term gemein (common) interchangeably with Gemeinde, a trend found also in the writing of Swiss political and church figures. ${ }^{28}$ Jakob Grimm observed that gemein was related to its Latin equivalent communis, which derived from the idea that all those who lived within the city walls were part of one municipality and enjoyed certain collective rights. ${ }^{29}$ Thus, gemein referred to something that was a concern for the general public, as well as groups that shared legal obligations. In his writings, Zwingli often invoked the terms Gemeinde or "brotherhood", and when writing in Latin he often referred to the Helvetians as a whole. ${ }^{30}$ For these reasons, we are primarily concerned with the lexicon relating to Gemeinde, what it meant to Zwingli during his lifetime, and how it helped shape the course of the Reformation in Zurich and beyond.

\section{Zwingli and the Corpus Christianum: Community, Confederation, and Reform}

\footnotetext{
${ }^{27}$ Scribner, "Communities and the Nature of Power," 294.

${ }^{28}$ Tom Scott has assessed some of Scribner's points rather effectively in Tom Scott, "Review: The Common People in the German Reformation," in The Historical Journal 34, 1 (March, 1991), 183-192; Scott, "Review: Peasant's Revolt in Early Modern Europe," in The Historical Journal 28, 2 (June, 1985), 455-468.

${ }^{29}$ Scribner, "Communities and the Nature of Power," 295. Cf. Jakob Grimm, Deutsches Wörterbuch IV (German Dictionary IV) (Leipzig, 1897), col. 3170 and J.F. Niermeyer and C. Van de Kieft, Mediae Latinitatis Lexicon Minus I (Leiden: Brill, 2002), 287-288. ${ }^{30}$ See for instance, Lee Palmer Wandel, "Brothers and Neighbors: The Language of Community in Zwingli’s Preaching," in Zwingliana 17/1 (1988), 361-374.
} 
Some of Zwingli's earliest extant writings demonstrate his anxiety and fear for the social and political forces that threatened the Confederation during the early sixteenth century. ${ }^{31}$ His early poetry like The Ox (1510) and The Labyrinth (1516) attacked the mercenary system and foreign intrusions into Swiss life, and they highlight Zwingli's desire to ensure liberty for the Confederation. ${ }^{32}$ These early examples illustrate that from the beginning of his ministry in Glarus, socio-political issues rather than personal ones influenced Zwingli's views. This eventually had profound effects for his program of reform since, unlike Luther, whose reform began by a personal dilemma, Zwingli first addressed questions relating to the socio-political situation in the Confederation before moving on to religious uncertainties. ${ }^{33}$ The fact that his early writing does not address specific theological concerns suggests that only later during his ministry did Zwingli feel the need to articulate his theological position. His early writing also shows that despite his location in a distant part of Switzerland, Zwingli saw any threat to the Confederation as having a direct impact on him. By the 1520s, Zwingli's writing began to emphasize the importance of community and religious change for the entire Confederation, and his ideas relating to the church and sacraments elucidate this. Although he thought the Reformation enterprise was crucial for all true Christians, Zwingli wrote about the significance of reformation for the Confederation and in particular stressed that "the Swiss should not be counted among the Germans.",34 Instead, Zwingli declared, "I am Swiss, and I proclaim Christ to the Swiss." 35 Though he recognized the individuality of Swiss cities, Zwingli frequently referred to the importance of "the Helvetians" as a whole. ${ }^{36}$ This emphatic declaration was part of a common trope among Swiss humanists of the early sixteenth century and propagated by Glareanus.

The following sections explore systematically Zwingli's ecclesiology and his writings on baptism and the Lord's Supper. This

\footnotetext{
${ }^{31} \mathrm{Z}$ I, 23-37.

${ }^{32}$ Z I, 1-22; 39-60.

${ }^{33}$ Wilhelm Bender, Zwinglis Reformationsbündnisse (Zwingli's Reformation Alliances [Covenants]) (Zürich: Zwingli Verlag, 1970), 129ff.

${ }^{34} \mathrm{Z}$ I, 270 "Hevetii autum inter Germanos non censeantur."

${ }^{35}$ Z I, 270 "Helvetius et apud Helvetios Christum profitens"

${ }^{36}$ Z VIII, 84-89. "Det deus Helvetiorum genti mentem amplectendi sermonem suum!"
} 
section also highlights the importance of chronology in Zwingli's thought and experience, since the ongoing controversy between the inchoate Anabaptist movement helped shape his ideas about community after 1523 .

\section{Community Membership in Zwingli's Ecclesiology}

While Zwingli wrote frequently during his ministry at Glarus, his arrival and ascension to the pulpit at the Grossmünster (The Great Minster) in 1519 provided him with an opportunity to preach to one of Switzerland's largest congregations. For Zwingli and the Reformation in Zurich, 1523 marked a pivotal year for many reasons, not least because after many disputes the city council allowed Zwingli to preach directly from Scripture, a shift reflected in his writing. Throughout the 1520s he continued to oppose both the foreign encroachments in Swiss lands and the pension system, and by 1524 he became increasingly concerned about how he and other theologians could reform the church, and whether images and the Mass should be eradicated. ${ }^{37}$ In one of his most significant treatises, Commentarius de vera et falsa religione (1525), Zwingli addressed twenty-nine social and spiritual issues, including purgatory, charity, and the law. Historians like Gottfried Locher refer to the Commentarius as "the first comprehensive dogmatics of the Reformation," 38 and it remains a fertile source for scholars interested in Zwingli's concept of community and his ecclesiology. ${ }^{39}$ In this treatise, Zwingli demonstrated his view of the church as a corporate, universal, and common congregation for all Christians. Zwingli envisioned a common confederate church in which all members were bound to each other through belief in the Gospels and through the actions of baptism and the Lord's Supper. ${ }^{40}$

In the Commentarius, Zwingli devoted particular attention to the meaning of church and wrote about the development of the word in each

\footnotetext{
${ }^{37}$ Z III, 92-96, 114-131.

${ }^{38}$ Gottfried W. Locher, Zwingli's Thought: New Perspectives (Leiden: Brill, 1981), 239.

${ }^{39}$ CRR 905-911/1-2265 "De vera et falsa religione commentarius"

${ }^{40}$ Alfred Farner, Die Lehre von Kirche und Staat bei Zwingli (The Doctrine of Church and State in Zwingli's Thought) (Tübingen: Verlag von J.C.B. Mohr, 1930), 3-4.
} 
biblical language as well as German. Recent research by Hildegard Keller shows that Swiss Reformers after 1531 portrayed themselves as an elect people, likening themselves to the people of Israel. ${ }^{41}$ However, some of the earliest examples of this rhetoric came from Zwingli in the 1520s. In 1525, he delineated the development of the word Ecclesia from its Greek predecessor to its (Swiss) German equivalent, kilch. "This word Ecclesia," Zwingli wrote, "also adopted and used by the [Romans], in the Holy Scriptures means a gathering, now certainly a multitude, a whole people of Israel." ${ }^{, 4} \mathrm{He}$ sought first and foremost to explain his ecclesiology within the framework of the Hebrew Bible, before applying it to the context of the New Testament. In this way, Zwingli believed he needed to guide his confederates just as "In Exodus 12, God says to Moses: speak to the entire multitude of Israel's children." ${ }^{, 43}$ It was clear for Zwingli that the Confederation, and those residing within it, were the chosen people. For this reason, it was imperative that the confederates understood the differences between true and false religion, between real Christianity and the perverted version that had dominated Christendom for centuries. Although he believed that "we, just like the children of Israel, have to suffer," Zwingli was certain that instituting religious reform would at once unite his people and bring about a fundamental regeneration. $^{44}$

When not invoking rhetoric of the children of Israel, Zwingli expounded his ecclesiology and church membership in the context of the New Testament. Paul's writings formed an integral part of his understanding of the church as a corporate and universal entity, which consisted not of hierarchies but of a common love in Christ. In his reading of Matthew 25, however, Zwingli realized that although the true church consisted of all those who participated in the true sacraments, it would take a constant effort to purify his church.

\footnotetext{
${ }^{41}$ Hildegard E. Keller, "God's Plan for the Swiss Confederation," in Orthodoxies and Heterodoxies in Early Modern German Culture: Order and Creativity, 1550-1750 edited by Randolph C. Head and Daniel Christensen (Leiden: Brill, 2007), 139-167.

${ }^{42}$ CRR 905-911/1-2265, 111-112.

${ }^{43}$ CRR 905-911/1-2265, 111-112.

${ }^{44}$ CRR 905-911/1-2265, Introduction.
} 
He concluded that "Church means a whole flock, a whole congregation, a whole common people... a whole community." ${ }^{45}$ Later, in the same treatise, Zwingli rejected the episcopate as a defining characteristic of the church when he argued that "such a universal church is not an assembly of popes/bishops etc.," but rather a common congregation of all pious believers. ${ }^{46}$ For Zwingli, Scripture proved the most authoritative in defining church membership, and he often used pericopes from Matthew to show what church meant to Jesus. ${ }^{47}$ The language Zwingli used to describe the church testifies to a strong connection among church membership, communal definition, and the universality of the church. If this view could be spread throughout the Confederation, Zwingli believed, each individual in the community would become a member of a broader corpus christianum. This treatise, printed in both Latin and German, sought to clarify Zwingli's position on the sacraments and the pastoral questions surrounding the Reformation in Zurich during the $1520 \mathrm{ss}^{48}$

In his other writings, regarding marriage for instance, Zwingli's lexical choices on Confederation and community show that he used the two terms closely together. In the introduction of Regarding Godparenthood (1525), Zwingli addressed his treatise to all the common people of the Confederation, to the "common man," and the "common Christian man." ${ }^{49}$ His closing expressed his love for the Confederation and all Christians residing in it. Again, employing such language broaches questions surrounding his usage of "community" and "common" as rhetorical constructions. In addition, Zwingli also likened marriage to a holy alliance to which two individuals pledged allegiance

${ }^{45}$ CRR 905-911/1-2265, 124 "Kilch heißt ein gantze schar, ein gantze versamlung, ein gantz allgemeyn volk, ein gantze menge, ein gantze gemeind."; cf. Z III, 741 "Ecclesia enim coetus est, concio, populus universus, collecta simul universa multitudine." ${ }^{46}$ CRR 905-911/1-2265, 136 "Sölich Allgemeyne (Ecclesia Katholica) ist nit eyn versamlung de bäpsten/bischoffen, etc. sunder aller heilige, das ist aller fromen gloubigen gemeynsame.” Cf. Z II, 683.

${ }^{47}$ CRR 905-911/1-2265, 128 "Matthei 13. Hie lernend wir, das die gantze menge der Christen, die sich furr gloubig schetzend, ein gloubig volck, ein Ecclesia, ein kilch genennet wirt.”; cf. Z III, 744-745

${ }^{48}$ Richard Stauffer, "Einflu $\beta$ und Kritik des Humanismus in Zwinglis 'De vera et falso religione commentarius'," Zwingliana XVI/2 (1983), 97-110.

${ }^{49}$ CRR 303/1-878, 1-11. "den ich u $\beta$ not andrer, nit min, an alles volk gemeiner Eydgenoschaft schryben muß.”; “...das sich die, so dise ding mit gwalt dem gmeinen Christen man uff de[mals?] wellend gebunden han..." 
in the presence of God and the community: "therefore, we should recognize marriage as a holy alliance and duty.",50

Another example of this usage can be found in the protocols of the second disputation in 1523. In his opening address, Zwingli highlighted the uniformity upon which his concept of the church was based. He emphasized once more that all pious believers belonged to the church, and speeches made by Leo Jud (1482-1542), a key figure in the Swiss Reformation, suggest that some of Zwingli's closest colleagues viewed the church in a similar light. ${ }^{51}$

These examples illustrate that Zwingli intimately linked his ecclesiology to a universal community, a katholikós church in the true sense of the word. Although he explicates his ecclesiology explicitly in the Commentarius, Zwingli alluded to the "common people" and the Confederation in treatises that did not always directly address his ecclesiology. Zwingli's rhetorical use of community was inherently linked to his definition of the church, which he saw as a universal body of believers regardless of proximity.

Though his ecclesiology remained static throughout his lifetime, Zwingli's concepts of baptism and the Lord's Supper, and how these sacraments defined community membership, fluctuated with growing concern over Anabaptism and the increasing opposition to his teachings throughout the Swiss lands. Nonetheless, Zwingli believed the sacraments provided a channel through which each member pledged allegiance to the community and to the broader Christian corpus. Together with his ecclesiology, an examination of Zwingli's writing on the sacraments helps to understand how they determined community within the Confederation.

\section{Baptism, the Lord's Supper, and Community}

Peter Stephens's work shows that Zwingli expressed his view on the sacraments in a series of controversial writings that gave a greater

${ }^{50}$ CRR 905-911/1-2265, 133.

${ }^{51}$ Z II, 681-690. See Leo Jud's speech and his emphasis on "der allgemeinen christlichen kilchen”. 
emphasis to the opinions he rejected than to those he held. ${ }^{52}$ In the Commentarius, Zwingli wrote that "Christ has left us two Sacraments: baptism and the Lord's Supper." 53 He rejected the use of the term "sacrament" because all other rituals of the Catholic Church were more ceremonial than efficacious, and did little to demonstrate Christ's goodness and sacrifice. ${ }^{54}$ Zwingli also opposed the use of the word for philological reasons; mysterion in Greek does not have the same range of meanings as its Latin equivalent, sacramentum. ${ }^{55}$ For baptism and the Lord's Supper, however, Zwingli willingly accepted the term "sacrament" if it referred to a sign or seal, and in many cases he described the sacraments as pledges. ${ }^{56}$ Importantly, he also understood these pledges or sacraments as an oath to other members of the community, presenting them analogously in militaristic terminology:

And so [the word] 'Sacrament' really means a sworn oath, and it is still used to this day by the Italians and the French in their languages. It is also a Sacramentum militare, a statutory duty, which soldiers swear to their captain according to the customs and form of military law (for war also has its own law)... 'Sacrament' is nothing other than a commitment or obligation... If you commit yourself, and you have bound yourself by the sign [zeychen] and oath [pflicht] of your duty, you should remain true to your oath and honor your obligation. ${ }^{57}$

This is particularly important for Zwingli's view of community, since he applied the term "pledge" to the sacraments as "an inward and outward union of Christian people." ${ }^{58}$ For Zwingli, the pledges of baptism and the Lord's Supper were the most crucial in defining

\footnotetext{
${ }^{52}$ W. P. Stephens, The Theology of Huldrych Zwingli (Oxford: Clarendon Press, 1986), 180.

${ }^{53}$ CRR 905-911/1-2265 "zwey Sacrament hat uns Christus hinder gelassen: den Touff unnd das Nachtmal des Herren"

${ }^{54}$ CRR 905-911/1-2265 "die andren Sacrament sind me ceremonien dan zeychen."

${ }^{55}$ CRR 905-911/1-2265, 131.

${ }^{56}$ Zwingli uses Pflicht for "pledge" and sometimes Pflichtzeichen for a "pledge of allegiance.” E.g. Z III, 227.

${ }^{57}$ CRR 905-911/1-2265, 131.

${ }^{58}$ Z II, 808-809; Z III, 114-131; see also Zwingli Hauptschriften (edited by Fritz Blanke, Oskar Farner, and Rudolf Pfister III. Teil (Zürich: Zwingli Verlag, 1948), 17-66. “Also ist der Touff im nüwen Testament ein pflichtig Zeichen,...”
} 
community; one entered the community by baptism and then pledged and maintained allegiance to it through the Lord's Supper.

Until the second dispute in 1523 , Zwingli wrote very little about baptism. After 1523, when Conrad Grebel, Felix Mantz, and their followers called into question the scriptural validity of infant baptism, Zwingli's view on the sacrament became more pronounced. From his earliest writing on baptism, it is clear that his emphasis lay on faith rather than on baptism. As Stephens rightly acknowledges, Zwingli initially held an ambiguous attitude toward infant baptism since he hesitated to declare infant baptism as scripturally sound. ${ }^{59}$ The growing concern over Anabaptism led Zwingli to reflect on the spiritual value of the sacrament. While he acknowledged that baptism was a sign, Zwingli distinguished it from a miraculous sign that merely represented the power the sacrament meant to convey; he understood baptism as a pledge or oath, which did not necessarily strengthen one's faith. In Baptism, Anabaptism, and Infant Baptism (1524), Zwingli considered baptism as found in the Scriptures in the context of John 3:22, Matthew 21:25, and I Peter 3:21, and he described baptism as a pledge by which Christians demonstrated their outward commitment to Christ and other members of the church. ${ }^{60}$ Zwingli's position on baptism complemented his view on God's grace and the sovereignty of God, which meant that baptism was never enough to forgive sinfulness because, Zwingli believed, "God's grace is greater than our sin." 61 Baptism represented God's covenant of grace, reflecting his promise and greatness since his covenant with Abraham. ${ }^{62}$ Zwingli saw baptism as necessary because the Scriptures highlight its importance in a variety of passages. The most crucial, however, was its role in the initiation of believers and those who were going to believe in Christ. ${ }^{63}$ For Zwingli, baptism represented an initiation into the community of

\footnotetext{
${ }^{59}$ Stephens, The Theology of Huldrych Zwingli, 194.

${ }^{60} \mathrm{Z} \mathrm{IV}, 241$.

${ }^{61}$ CRR 338/1-995. "die gnad gottes ist grosser dann unsere missethat"; "Die Sel mag kein Element oder usserlich Ding in diser Welt reinigen, sunder Reinigung der Sel ist der einigen Gnad Gottes." Zwingli Hauptschriften, 150; Z IV, 252.

${ }^{62}$ Z IV, 596.

${ }^{63}$ W. P. Stephens, Zwingli: An Introduction to his Thought (Oxford: Clarendon Press, 1992), 86.
} 
believers: "with baptism one enters their community and this sign initiates them into the people of God." 64

Heinrich Bullinger, Zwingli's successor, echoed some of these very notions, indicating the extent to which Zwingli's ideas, not to mention language, influenced other Swiss theologians. In his Anklag (1528), Bullinger wrote:

"Dear confederates, bear in mind that in baptism you have bound yourself to me with a stronger oath $[E y d]$ than that which binds you among yourselves in one place to another. The oath $[E y d]$ that you wish to recognize me as your only God supersedes all customs, practices and traditions. Of this I sternly remind you now." 65

To paraphrase Keller, this type of rhetoric, and particularly the use of eyd, zeychen, or pflicht, referred to both the political alliance among the Confederates as well as to the covenant between God and the Confederates, the latter of which remained the most important to Zwingli and his colleagues. ${ }^{66}$

When concerned with baptism, much of Zwingli's effort concentrated on expounding his thought in light of the Anabaptist controversy; so he often discussed baptism in relation to his opponents. His ideas on baptism, therefore, did not always reflect the purposes of baptism, but rather a defense of his view on the sacrament. His writings on the Lord's Supper, on the other hand, are more helpful in that they are much less a defence than an exposition of the sacrament's qualities and its effects on the community. For Zwingli, as Julius Schweizer has rightly pointed out, the Lord's Supper presented both theological and pastoral problems during the 1520 s because a reformation of this sacrament also required a reformation of social praxis. ${ }^{67}$ Moreover, while the Anabaptist controversy primarily centered on the Swiss lands, Zwingli's teaching on the Lord's Supper received harsh scrutiny from

${ }^{64}$ Z IV, 682; Z IV 707-711.

${ }^{65}$ As cited in Hildegard Keller, "God's Plan for the Swiss Confederation," 143.

${ }^{66}$ Keller, "God's Plan for the Swiss Confederation," 142.

${ }^{67}$ Julius Schweizer, Reformierte Abendmahlsgestaltung in der Schau Zwinglis (Reformed Communion in Zwingli's Acts) (Basel: Verlag Friedrich Reinhardt, 1954), 60-68. 
theologians throughout Europe. From the beginning, Catholics and Lutherans alike associated Zwingli's teaching on the Lord's Supper with radical implications, one of the reformer's legacies left for Heinrich Bullinger to flesh out after 1531.

In Analysis and Reasons for the Concluding Statements (1523),

Zwingli explained the Lord's Supper as a memorial to the sacrifice Christ made for humankind. Memorializing, for Zwingli, meant renewing and remembering what Christ did for all people, which acted as "an inward thanksgiving" that united Christians in a common body. ${ }^{68}$ According to Zwingli, the Catholic Church had erred for centuries in teaching that through transubstantiation, the priest transformed wine and bread into the blood and body of Christ. ${ }^{69}$ Zwingli wrote that speculating about the real presence of Christ during Mass was unavailing since he knew that Christ was at the right hand of God; wherever that was, he could not be physically present at Mass. ${ }^{70}$ For Zwingli, the other more corporeal elements involved in the Lord's Supper helped reinforce its corporate and communal efficacy, which helped Christians live as Christ did. $^{71}$ When a member transgressed divine or secular law, Zwingli thought that sinners should be excluded from the Lord's Supper by banning them from their "community or church."72 In referencing I Corinthians 10, Zwingli argued that the Lord's Supper provided a means through which Christians could "testify to all men that we are one body and one brotherhood," once again emphasizing the strengthening of community through the sacraments. ${ }^{73}$ The Lord's Supper symbolized that: just as Christ sacrificed himself for humankind, Christians are also bound to give themselves to each other, "as for one's brother, indeed as for one's own member." 74 According to Zwingli, the Lord's Supper

${ }^{68}$ Z II, 137-138.

${ }^{69}$ Z VIII, 85.

${ }^{70} \mathrm{Z}$ II, 113. "Aber Christus ist nit in ein sölichen temple, sunder in der himel inggangen"

71 Z II, 607.

${ }^{72}$ Z IV, 31. See also Roger Ley, Kirchenzucht bei Zwingli (Church Discipline in the Works of Zwingli) (Zürich: Zwingli Verlag, 1948), 34-38.

${ }^{73}$ Z III, 124-125.

${ }^{74}$ Z III, 227. "Und sölich eingkeit under den Christglöubigen zů bestäten, hat er ee und er in ' $n$ tod gieng, ein gmächt oder sacrament ufgericht, damit wir Christen uns ewigkeit zesamen pflichtend gegen einandren, glych wie uns Christus mit gott verpflicht hat...zu einer pflicht, das sy ein lynchnam und gemeine brůderschafft sin wellind...als für uns geben hat, sich ouch ein yeder für sinen bruder, als für sin glid" 
represented a memorialization of Christ's goodness and sacrifice, a time for Christian reflection, and, significantly, a symbol of each individual's continuous commitment to the community and corpus christianum. ${ }^{75} \mathrm{He}$ characterized succinctly his view on the Lord's Supper as "nothing more than a thanksgiving, a communal rejoicing" and emphasized its importance for the community and church. ${ }^{76}$ It was essentially a "communal arrangement of believers.",77

While Zwingli used the Lord's Supper to reinforce his notion of community, it was also used in the opposite way: to punish and exclude, thereby further defining the frontiers of community. Concerning the Lord's Supper, he wrote "hence [the church] is also an association or corporation: in that case, then, the ban or exclusion and seclusion from this community of believers" would be apt for those who transgressed both ecclesiastical and secular law. ${ }^{78}$ It is no coincidence, therefore, that the exposition of these ideas coincided with heightened attempts to regulate salacious behaviour, beginning first with Zurich's marriage court (Ehegericht) in May 1525, followed by a variety of similar morals courts implemented throughout the Swiss lands.

An examination of Zwingli's writing on baptism and the Lord's Supper highlights the connection between his ecclesiology and the sacraments, in that each Christian belonged to a common and universal church. Through baptism, individuals entered a universal Christian community and pledged allegiance to each other through the Lord's Supper, which also memorialized Christ's sacrifice and brought the community closer to him. Zwingli's writing on the sacraments makes clear how they reinforced community definition; yet a focus on his rhetorical concept of community also raises questions about the breadth of Zwingli's quixotic community. Did his concept of community include individuals from outside the Confederation, or was he concerned

\footnotetext{
${ }^{75}$ CRR 338/1-955 “... ist ghein andre ursach den gmein christus, der uns brůder und glid eines lybs macht."

${ }^{76}$ CRR 905-911/1-2265. "Also verstond wir yets ufs dem namen was Eucharistia, was das Nachtmal des Herre sye: namlich nüt anders, dann ein dancksagung, ein gmeine frolockung."; cf. Z III, 773-803.

${ }^{77}$ Z III, 228; Z IV, 773.

${ }^{78}$ CRR 905-911/1-2265, 148.
} 
primarily with uniting the Swiss lands through evangelical preaching? Was Zwingli's concept of community bound strictly to Zurich, as Walton has argued? And finally, why did Zwingli fear the rejection of the Reformation in other parts of Switzerland?

\section{Zwingli's Concept of Community and the Confederation}

The salvation of the Confederation, Zwingli believed, depended on successfully spreading the Reformation. In 1524, he wrote that "nothing is able to help our honoured Confederation to peace and unity so well as the one God with his Word. Without doubt were it preached in the whole Confederation we could have no greater unity."79 A year later, he made it clear that without reformation, the unity of the Confederation was in peril not only spiritually but physically as well:

"For many years we have seen, where a prince, a lord, the pope, the bishops and their council has failed, they have been bound to cause a war. How often have we seen how they have broken the confederation? How many souls have been killed along the way? Not to mention the lives and the property, how much land has been spoiled? How many towns destroyed? How much damage has chastity and faith suffered?... we must call upon the one and only God and beg, he who has counted our standing force, that he may enlighten the minds of the princes (who in this world are lost in unhappiness), that they recognize God and themselves, that we may abandon the anti-Christian state of the Pope in rest and peace: then there is otherwise no need for despair, alone one abandons the Pope... For this reason, we shall beg to God fearfully, that all people fall away from the pope, (who) were solely devoted to the false Christ, simply look to God, who is our supreme Lord, Father and savior/Amen"

\footnotetext{
${ }^{79}$ As quoted in Siegfried Rother, Die religiösen und geistlichen Grundlagen der Politik Huldrych Zwinglis (The Religious and Spiritual Foundations of Huldrych Zwingli's Politics) (Erlangen: Palm \& Enke, 1956), 40.

${ }^{80}$ CRR 905-911/1-2265, 265-266.
} 
After 1525, however, tensions continued to mount between the reformed and Catholic cantons of Switzerland when Uri, Schwyz, Unterwalden, Lucern, and Zug formed a bloc (die fünf Orte) in opposition to Zwingli's reformation. Despite the confessional division of the Confederation, Zwingli believed that reformation could unite the Swiss and he stressed emphatically the importance of a universal and common church among the Swiss. This epitomized Zwingli's idea of community. He refused to see the decisions made at the Diet of Worms (1521) as applicable to the Confederation, by emphasizing the Reformation in the Swiss lands as a national enterprise. By 1526, Zwingli accused the Catholic confederates of restricting Swiss liberty, since they adhered to the results of a German diet. ${ }^{81}$ Nevertheless, the Baden disputation took place on 19 May 1526 and sought to prove the uselessness of the Bible, to which Zwingli and his followers turned as the sole authority of Christianity, and to stress the importance of tradition. All the Confederates sent delegates except Zurich, which meant that Johannes Oecolampadius represented both reformed Switzerland and Zwingli. Oecolampadius rebuked the position of the Catholic Church and its representative Johan Eck. ${ }^{82}$ Even though Zwingli was not present, his colleagues kept him informed on the progress via correspondence and pamphlets. ${ }^{83}$ After he read one of Eck's treatises, Zwingli rebutted that "Swiss distrust of foreigners is strongly fanned." ${ }^{84}$ In the end, the dispute in Baden established Zwingli's teaching as heretical and showed that the issue of religion irreclaimably fragmented the Confederation, though Zwingli refused to realize this. It demonstrated, furthermore, that members of the Confederation willingly entered into alliances with nonConfederation states as long as they held a common confessional ground. Following the meeting in Baden, the Catholic cantons formed the "Christian Alliance" with Ferdinand of Austria, while the Protestant

${ }^{81} \mathrm{Z} \mathrm{V}, 171$.

${ }^{82}$ Oskar Farner, Huldrych Zwingli: Reformatorische Erneuerung von Kirche und Volk in Zürich und in der Eidgenossenschaft, 1525-1531 (Huldrych Zwingli: Reformation and Renewal of Church and People in Zurich and the Confederation, 1525-1531) (Zürich: Zwingli Verlag, 1960), 183-208.

${ }^{83} \mathrm{Z} \mathrm{V}, 215$.

${ }^{84}$ As quoted in Locher, Die Zwinglische Reformation im Rahmen der Europäischen Kirchengeschichte (The Zwinglian Reformation in the Context of European Church History) (Göttingen: Vandenhoeck und Ruprecht, 1979), 186. 
cantons entered into the "Christliche Bürgerrecht". Significantly, this dispute also led Zwingli to speculate further on the importance of spreading the Reformation to other parts of Switzerland. ${ }^{85}$

The developments that followed in the late 1520 s, such as the disputation in Bern (1528) and the First Kappel War (1529), highlight Zwingli's certitude to spread the Reformation and establish a broader Swiss community, which, for Zwingli, remained a realistic possibility despite such vehement religious and political opposition. The evidence available from the disputation in Bern and Zwingli's sermons following the meeting helps illustrate that he thought about community transcendently, one centred around the Swiss and neither limited to parish nor diocesan boundaries.

Until 1527, Bern's position toward the Reformation remained ambiguous. In the same year, an election took place in the city and a majority of magistrates desiring reform were elected to city council. Gäbler notes that we have no detailed investigation of this power transfer but it is likely that guilds instigated the shift. ${ }^{86}$ To settle the Reformation question in Bern, the city council held a disputation in January 1528 aimed to supersede the meeting in Baden two years prior. Cities from throughout the Confederation sent delegates, including Zwingli, as well as Protestant theologians from outside the Swiss lands like Martin Bucer and Wolfgang Capito. ${ }^{87}$ This meeting provided Zwingli with a forum through which he could win confederates to the Reformation's cause, an idea to which he alluded through correspondence with Niklaus von Wattenwyl as early as $1523 .^{88}$ Zwingli took the floor more than a hundred times and the debate largely centred on topics which he addressed before, like concepts of church, authority of Scripture, and marriage. ${ }^{89}$ The majority of his notes taken during the disputation demonstrate his steadfastness and conviction to spread what he believed

\footnotetext{
${ }^{85}$ Thomas A. Brady Jr., Turning Swiss: Cities and Empire, 1450-1550 (Cambridge: Cambridge University Press, 1985).

${ }^{86}$ Gäbler, Huldrych Zwingli, chapter 7.

${ }^{87}$ Farner, Huldrych Zwingli: Reformatorische Erneuerung von Kirche und Volk in Zürich und in der Eidgenossenschaft, (Huldrych Zwingli: Reformation and Renewal of Church and People in Zurich and the Confederation, 1525-1531), 264-288.

${ }^{88}$ See letter to Niklaus von Wattenwyl from 1523 in which Zwingli discussed the idea of pan-Confederation reform, Z VIII, 101-105; 134-135.

${ }^{89}$ Gäbler, Huldrych Zwingli, 117-118.
} 
to be a true church of Christ, stressing once more that "the head of this church is Christ, he is our leader and captain." 90 This universal church, Zwingli continued, "is not a collection of cardinals and bishops and of spiritual servants, but a congregation of those who trust and believe God." 91 The disputation resulted in Bern adopting the Reformation and drawing up a Reformation Mandate, acts which effectively split the Confederation into two confessional camps. ${ }^{92}$

Zwingli concluded his travels in Bern with two sermons delivered on 19 and 30 January 1528. In both, he reiterated the universality and inclusivity of the church and, once again, expressed his renunciation of the episcopate as a defining feature of the true church. Instead, Zwingli believed the keepers of the church should unite with the common people in one congregation, which raises the question of how the church writ large would operate. ${ }^{93}$ Zwingli also explicitly mentioned the progress of reformation undergone in cities like Basel and lauded reformed cities for forming a church that included all true Christian believers. $^{94}$ On the other hand, Anabaptists, Zwingli explained, segregated themselves from this true and universal church to establish their own because they wished to cut away from the rest of the church and community. He distinguished between a "common" or "universal" church of Christians and those who wished to "isolate" or "sever" themselves from the community. ${ }^{95}$ At the end of his second sermon, Zwingli remarked optimistically that the relationship between their neighbours and confederates would ultimately become better than ever. ${ }^{96}$ The situation in the Confederation, however, was much more volatile than Zwingli acknowledged in his sermons and writing. By 1529, the tensions between Catholic and Reformed alliances came to a head, resulting in the First Kappel War and an advantage for Reformed

\footnotetext{
${ }^{90}$ Z VI, 248-250.

${ }^{91}$ Z VI, 249.

${ }^{92}$ Z VI, 504-508.

${ }^{93} \mathrm{Z}$ VI, 489. "Et unam catholicam et apostolicam ecclesiam, ein heylige, allgemeine unnd apostolishe kilchen."

${ }^{94}$ Z VI, 490.

95 Z VI, 489-491. "zerschnittne" (abgeschnitte) and "sündrung" (Absonderung) in contrast to "allgemeine, christliche kilchen" or "gmeinsame der heyligen."

${ }^{96}$ Z VI, 498. “... werde ouch unsere lieben nachpuren, die übrigen Eydgnossen, zů syner zyt ziehen, das wir in warer fründschafft, die got ouch erlyden mag, ba $\beta$ einhällig werdind weder [als] vormals ye."
} 
Switzerland. ${ }^{97}$ The most pertinent clause included in the peace treaty was Zwingli's demand for the unimpeded preaching of the Gospel in all areas of the Confederation and interior Switzerland. ${ }^{98}$ This demand, written explicitly in the treaty, would enable Zwingli to incorporate the Confederation into a common and universal church. ${ }^{99}$ It effectively established the legal basis on which a pan-Confederation reform could build, and this remained Zwingli's goal until his death two years later at the Second Kappel War in $15311^{100}$

The evidence above demonstrates that Zwingli saw the Confederation as vital to the spread of the Gospel and to his reformatory program. Some historians, Hildegard Keller for instance, have noted that during the Reformation Swiss reformers coloured themselves as an elect people, seeing confessional conflict in both religious and political terms. ${ }^{101}$ In this way, the Reformation of the entire Confederation was a precondition for remaining God's elect. ${ }^{102}$ Although Keller largely focuses on Reformation Zurich after 1531, many of the ideas expressed in her work are applicable for Zurich during Zwingli's time. In some treatises, he thanked his colleagues from different parts of the Confederation, like Thomas Wyttembach and Berchthold Haller, for assisting him in preaching the Gospel. ${ }^{103}$ While outside of Zurich, Zwingli consistently repeated his ecclesiology and his position on the sacraments, and he almost always spoke about his ideas in a confederal framework. The successful implementation of the Reformation in Bern after 1528 and the treaty resulting from the First Kappel War in 1529

${ }^{97} \mathrm{Z} \mathrm{VI}_{\mathrm{II}}$, 433-440; 460-467. Cf. Oskar Farner's Huldrych Zwingli: Reformatorische Erneuerung von Kirche und Volk in Zürich und in der Eidgenossenschaft, (Huldrych Zwingli: Reformation and Renewal of Church and People in Zurich and the Confederation, 1525-1531), 292ff.

${ }^{98} \mathrm{Z} \mathrm{VI}_{\mathrm{II}}, 460$.

${ }^{99} \mathrm{Z} \mathrm{VI}_{\mathrm{II}}, 460$. "Sittenmal in kurtzen jaren erst angefangen ist, gottes wort ynzwengen, und aber by ünseren vordren von ye welten har gottes wort nach vermög nüws und altes testaments fry gepredget warden ungestrafft und in allweg ungehindret in allen orten der Eydgnoschafft, in den undertone und zůgewandten, soverr einer, das er predget, mit gottes wort erhalten mag."

${ }^{100}$ See Emidio Campi, "Bullinger's Early Political and Theological Thought: Brutus Tigurinus" in Architect of Reformation: An Introduction to Heinrich Bullinger, 15041575 (Grand Rapids, MI: Baker Academic, 2004), 192-193.

${ }^{101}$ Hildegard E. Keller, "God's Plan for the Swiss Confederation," in Orthodoxies and Heterodoxies in Early Modern Culture: Order and Creativity, 1550-1750 edited by Randolph C. Head and Daniel Christensen (Leiden: Brill, 2007), 139-167.

${ }^{102}$ Keller, "God's Plan for the Swiss Confederation," 141.

${ }^{103} \mathrm{Z}$ II, 473. 
reveal that Zwingli strove to incorporate the Confederation into his universal church by cooperating with his colleagues outside of Zurich. At the same time, he vilified Anabaptists throughout the Confederation for their rejection and distortion of Scripture and for combating his church. Wilhelm Bender has argued that Zwingli attempted to create a "Christian state" in the Confederation, starting with a new Christian society in Zurich - an argument that followed Walton's interpretation. ${ }^{104}$ But his efforts to establish a universal church in the Confederation were hindered by vehement opposition from Anabaptists and Catholics alike. Nevertheless, Zwingli's lexicon relating to community in the context of the Confederation illustrates that he wrote and preached about community in its broadest and universal sense, which hinged on his ecclesiology and his explication of the sacraments. His desire not only to reform Zurich but to spread reformed teaching throughout the Confederation led him to preach in other cities and justify waging war against neighbouring cantons. It is clear from Zwingli's writing that he saw a reformation as a necessity for the Confederation, despite so much opposition, and he expressed this concern with a sense of urgency. In a letter to the people of the Toggenburg, Zwingli warned that unless they began preaching from Scripture his fatherland would remain in a state of blasphemers, gamblers, and adulterers. ${ }^{105}$ In his writing, Zwingli regarded the Reformation as an enterprise that would inevitably affect the entire Confederation and all "Helvetians" residing within.

\section{Conclusion}

This investigation discusses how historians have approached early modern community building and how the vast majority of scholars look at "actual" definitions of community as opposed to rhetorical or idealistic notions. This paper demonstrates that Zwingli's quixotic concept of community transcended local and corporeal boundaries to include a much broader space and, therefore, also contests Ferdinand

\footnotetext{
${ }^{104}$ Bender, Zwinglis Reformationsbündnisse, (Zwingli’s Reformation Alliances [Covenants]), 130 .

${ }^{105}$ Z VIII, 210-211.
} 
Tönnies' definition of the pre-modern Gemeinschaft. Zwingli's imagined community extended well beyond the locality of Zurich, a community which was principally defined through church membership and participation in the sacraments. The sacrament of baptism acted as an initiation into the community while the Lord's Supper represented a pledge of allegiance to the church and all members within it. Through disputations, correspondence with other theologians, and conducting campaigns against Catholics and Anabaptists, Zwingli hoped to spread evangelical preaching to the Confederation and to incorporate the Helvetians into a common and universal church. A confederal Reformation would have indicated to Zwingli and his followers that the Swiss remained God's elect. Ultimately, however, an apparent contradiction in Zwingli's writing emerges: on the one hand, Zwingli believed that bringing the Swiss into a common religious reform would strengthen the Confederation, but, conversely, the spreading of religious reform presupposed the fundamental existence and solidarity of the Confederation. These two contrasting issues remained irreconcilable for the rest of Zwingli's life. While the Confederation became a biconfessional collection of states after 1531, it was a non-confederate, but no less Swiss, republic that took on the essence of the Reformed (Zwinglian?) tradition in the Swiss lands. Zwingli's Gemeinde as Confederation never materialized.

Nevertheless, an examination of his writing highlights the intimate relationship between Zwingli's ecclesiology, his concept of community, and the desire to spread the Reformation to other parts of the Confederation. Although few historians look at rhetorical concepts of community definition in early modern Europe, they remain an important component in understanding how sixteenth-century reformers and theologians viewed the environments in which they lived and how they hoped to change them. 